University of Nebraska - Lincoln

DigitalCommons@University of Nebraska - Lincoln

Water balance in the sugarbeet root maggot Tetanops myopaeformis, during long-term low-temperature storage and after freezing

\author{
George D. Yocum \\ USDA-ARS Red River Valley Agricultural Research Center, george.yocum@ars.usda.gov \\ Joseph P. Rinehart \\ USDA-ARS, Rinehart@ars.usda.gov \\ Mark A. Boetel \\ North Dakota State University, mark.boetel@ndsu.edu
}

Follow this and additional works at: https://digitalcommons.unl.edu/usdaarsfacpub

Yocum, George D.; Rinehart, Joseph P.; and Boetel, Mark A., "Water balance in the sugarbeet root maggot Tetanops myopaeformis, during long-term low-temperature storage and after freezing" (2012).

Publications from USDA-ARS / UNL Faculty. 1135.

https://digitalcommons.unl.edu/usdaarsfacpub/1135

This Article is brought to you for free and open access by the U.S. Department of Agriculture: Agricultural Research Service, Lincoln, Nebraska at DigitalCommons@University of Nebraska - Lincoln. It has been accepted for inclusion in Publications from USDA-ARS / UNL Faculty by an authorized administrator of DigitalCommons@University of Nebraska - Lincoln. 


\title{
Water balance in the sugarbeet root maggot Tetanops myopaeformis, during long-term low-temperature storage and after freezing
}

\author{
GEORGE D. Y OCUM ${ }^{1}$, J OSEPH P. R INEHAR T ${ }^{1}$ \\ and MARK A. BOETEL ${ }^{2}$ \\ ${ }^{1}$ USDA-ARS Red River Valley Agricultural Research Center, Biosciences Research Laboratory, Fargo, North Dakota, U.S.A. and \\ ${ }^{2}$ Department of Entomology, North Dakota State University, Fargo, North Dakota, U.S.A.
}

\begin{abstract}
The sugarbeet root maggot Tetanops myopaeformis Röder (Diptera: Ulidiidae) can be stored in moist sand at $4-6{ }^{\circ} \mathrm{C}$ for up to 5 years and is freeze-tolerant. The majority of stored larvae survive in a state of post-diapause quiescence and the remainder are in a multi-year diapause. The present study aims to determine larval water content and water loss rates in diapausing and low-temperature stored larvae. Body water content ranges from $57 \%$ to $70.1 \%$. Two distinct groupings of larvae are revealed based on dry weights. The first group consists of the diapausing larvae and larvae stored for 1 year. This group has significantly higher dry weights than the second grouping, which consists of the larvae stored for 2 and 3 years. There are no significant differences within each group. Larval water losses follow a first-order kinetic relationship with time. Larvae stored for 2 years lose water at a significantly higher rate than diapausing larvae. Larvae exhibit no active water uptake at storage temperatures. A freezing event does not induce a significant decrease in wet weights, nor does it increase larval water loss rates. These results indicate that metabolic water and the microclimate during storage are key factors enabling the long-term survival of T. myopaeformis larvae during low-temperature storage, and may provide insights for maintaining other insect species under similar conditions.
\end{abstract}

Key words. Diapause, low-temperature storage, overwintering, sugarbeet root maggot, Tetanops myopaeformis, water loss rates.

\section{Introduction}

There is an increasing need for high-quality insects for use in biocontrol, research, pollination and conservation programmes. A key component in meeting this need is the development of storage protocols. Currently, three general strategies are employed for the storage of insects: (i) subambient temperature storage of nondiapausing insects; (ii) storage of diapausing insects at overwintering temperatures; and (iii) cryopreservation in liquid nitrogen (Leopold, 1991, 1998, 2007; Van Lenteren \& Woets, 1988). Of these three strategies, the use of diapause for the storage of insects has received the least amount

Correspondence: George D. Yocum, USDA-ARS Red River Valley Agricultural Research Center, Biosciences Research Laboratory, 1605 Albrecht Blvd, PO Box 5674, Fargo, North Dakota 58102-2765, U.S.A. Tel.: +1 701239 1301; e-mail: george.yocum@ars.usda.gov of attention (Gilkeson, 1990; Tauber et al., 1993; Garcia et al., 2002; Foerster \& Doetzer, 2006).

The sugar beet root maggot Tetanops myopaeformis Röder (Diptera: Ulidiidae) is currently being investigated as a model for enhancing low-temperature insect storage. It is a major pest of sugarbeet in the Red Valley of North Dakota and Minnesota, U.S.A. Adult flies emerge in May and June and the females deposit eggs near the sugarbeet seedlings during mid to late June. Larvae complete their development by late July to September and then migrate $5-35 \mathrm{~cm}$ down into the soil and initiate diapause. By late March and early April, the larvae move to within $10 \mathrm{~cm}$ of the soil surface and pupate (Callenbach et al., 1957; Harper, 1962; Whitfield \& Grace, 1985; Anderson, 1986; Bechinski et al., 1989, 1990). The unique feature of T. myopaeformis that makes it a promising model system for exploring storage physiology is that the mature larvae can be stored in moist sand at $4-6{ }^{\circ} \mathrm{C}$ for up 
to 5 years. The majority of stored larvae survive storage in post-diapause quiescence and are able to resume development if exposed to favourable temperatures. The remaining larvae are in a state of prolonged diapause that can last at least 5 years (Chirumamilla et al., 2008). Sixty-two percent of larvae stored for 4 years pupate and, of those, $47 \%$ emerge as adults. Females that are maintained in cold storage for 4 years are fertile, and $81 \%$ of their eggs hatch (Chirumamilla et al., 2008).

Another remarkable feature of T. myopaeformis is that it is freeze-tolerant (Whitfield \& Grace, 1985; Rinehart et al., 2009). Two cold-tolerance strategies are commonly employed within Insecta. Most insect species are killed if freezing of extracellular body water occurs (e.g. freeze-intolerant). These species use various cryoprotectants to decreases the temperature at which their body water will freeze. By contrast, freezetolerant species have mechanisms that promote the freezing of extracellular body water (Chown \& Nicolson, 2004).

As a result of their large surface-to-volume ratio, insects are vulnerable to excessive body water loss. Therefore, insects have evolved a number of highly efficient mechanisms to manage and conserve body water (Wharton, 1985; Chown \& Nicolson, 2004). The issue of water loss is even more critical for diapausing insects because of their limited access to water (Danks, 2000). To decrease their water loss during diapause, insects employ a number of different strategies, such as microenvironment selection, physical barriers (e.g. cocoons or increased cuticular lipid layers) and a decrease in metabolism aiming to reduce water loss as a result of respiration (Danks, 2000). There is evidence that some diapausing insects can gain water during diapause by absorption (Yoder \& Denlinger, 1991, 1992; Yoder et al., 1994). Because of its central role in survival during diapause, water balance in T. myopaeformis is examined in the present study, aiming to further the understanding of the physiology responsible for the remarkable longevity of the species during lowtemperature storage. The objectives of the present study are: to characterize how water loss rates of T. myopaeformis change over the course of storage; to investigate whether a stress event (e.g. freezing) affects the ability of T. myopaeformis to maintain water balance; and to determine whether larvae of T. myopaeformis absorb water from the atmosphere during storage.

\section{Materials and methods}

Insects

All experiments were conducted on T. myopaeformis larvae collected during 2006-2011 in the Red River Valley of North Dakota and Minnesota, U.S.A., from fields surrounding St Thomas, North Dakota. Larvae were transported to the laboratory, washed to remove any surface soil and transferred into plastic bags with moist silica sand $(20 \mathrm{~mL}$ water per $500 \mathrm{~g}$ microcrystalline silicon dioxide CAS \#14808-60-7; Unimin Corporation, New Canaan, Connecticut). The larvae were stored at $4-6{ }^{\circ} \mathrm{C}$ in darkness.

\section{Water loss experiments}

Initial body masses (wet weight) of larvae were determined using a six-place balance (model UMT2; Mettler Toledo, Columbus, Ohio). The larvae were then placed individually into wells of a 24-well culture plate and the plate was transferred to a desiccator containing anhydrous calcium sulphate $\left(\mathrm{CaSO}_{4}\right.$; Drierite, Fisher Scientific, Pittssburgh, Pennsylvania) held at room temperature. Larval water loss was determined by weighing the individual larvae at various time intervals during their exposure to $\mathrm{CaSO}_{4}$. Upon completion of the water loss experiments, larval dry weights were determined by transferring the larvae to $65{ }^{\circ} \mathrm{C}$ and taking multiple readings until the weights remained constant (approximately 5 days). Water loss values were then calculated (Wharton, 1985):

$$
\begin{aligned}
& \text { Initial milligrams of water }=\text { wet weight }(\mathrm{mg}) \\
& \text { - dry weight (mg) } \\
& \text { Water loss rate }=\ln \left(m_{\mathrm{t}} / m_{\mathrm{o}}\right)
\end{aligned}
$$

where $m_{\mathrm{t}}$ is water mass at time $t$ and $m_{\mathrm{o}}$ is the initial water mass.

In experiments examining the effect of a freezing event on water loss, the larvae were weighed before and after they were frozen, and the post-freezing weight was used to calculate water loss values.

\section{Water loss and water uptake at storage temperatures}

Water loss during storage was measured as above, except that the larvae were held at storage temperature $\left(4-6{ }^{\circ} \mathrm{C}\right)$ during the experiment. To determine whether larvae were able to absorb water from the environment, the specimens from water loss experiments were transferred either to $100 \%$ relative humidity or placed on moistened filter paper at $100 \%$ relative humidity and the larval weights measured at 6 and $24 \mathrm{~h}$ after transfer. Water uptake experiments were conducted at the storage temperature.

\section{Freezing and supercooling point determination}

To verify that individual larvae froze, the larvae were placed individually in $0.2-\mathrm{mL}$ thin-wall polymerase chain reaction (PCR) tubes to which 30-gauge copper-constantan thermocouples were taped. Temperatures were recorded at 1-s intervals using an Omega HH506R data logger (Omega Engineering, Stamford, Conneticut). Larvae were cooled at $-1 \pm 0.1{ }^{\circ} \mathrm{C} \mathrm{min}{ }^{-1}$ using a Nalgene Cryo $1{ }^{\circ} \mathrm{C}$ freezing container (Thermo Fisher Scientific Inc., Rochester, New York) placed in a $-70{ }^{\circ} \mathrm{C}$ freezer. The tubes were removed from the $-70{ }^{\circ} \mathrm{C}$ freezer as the temperature began to decrease again after the peak of the latent heat of fusion (i.e. heat released as a result of freezing), and were then immediately transferred to a $-10{ }^{\circ} \mathrm{C}$ water bath. The larvae were maintained at $-10{ }^{\circ} \mathrm{C}$ overnight. 
Larvae that were frozen in direct contact with water (frozen wet) were treated as above, except that the PCR tubes contained a small piece of filter paper wetted with $10 \mu \mathrm{L}$ of water. Two exothermal peaks were observed in this experiment. A small peak occurred when the water on the filter paper froze, and it was followed by a much larger peak when the larvae froze. The frozen larvae were immediately transferred to 0.5 $\mathrm{mL}$ microcentrifuge tubes containing moist sand and placed into the $-10{ }^{\circ} \mathrm{C}$ water bath. All larvae were thawed before conducting the water loss experiments. Water loss rates were determined as above.

\section{Statistical analysis}

Statistical analysis was conducted using SIGMAPLOT, version 11 (Systat Software, Inc., Chicago, Illinois). The initial water mass, dry weight and water loss data were analyzed by one-way analysis of variance and, if appropriate, post-hoc mean comparisons were carried out with Tukey's multiple comparison procedure $(\alpha=0.05)$.

\section{Results}

\section{Initial water mass of stored larvae}

The mean initial water mass of the larvae varied significantly in the range $11.5-14.8 \mathrm{mg}(F=6.193$; d.f. $=3 ; P<0.001)$ (Fig. 1A). Larvae stored for 1 and 2 years had a body water content equivalent to that of diapausing larvae but significantly less water by weight than larvae that were stored for 3 years $(P<0.05)$. The mean of the dry weights of the larvae varied significantly in the range $6.1-9.4 \mathrm{mg}(F=13.937$; d.f. $=3$; $P<0.001$ ) (Fig. 1B). Analysis of the dry weights identified two statistically significant groupings of larvae $(P<0.05)$. The first group included the diapause larvae and larvae stored for 1 year and the second group consisted of the larvae stored for 2 and 3 years. The percentage body water of the larvae was in the range $57-70.1 \%$.

\section{Rate of water loss in stored larvae}

Graphing the natural $\log$ of $m_{\mathrm{t}} / m_{\mathrm{o}}$ produces a straight line, indicating that water loss in T. myopaeformis exposed to dry air involves a first-order kinetic relationship between water loss and time (Fig. 2) Water loss rates of diapausing and stored larvae varied significantly in the range 1.4-2.2\% $\mathrm{h}^{-1}(F=5.856 ;$ d.f. $=3 ; P=0.001)$. The only group that lost water at a significantly higher rate $(P<0.05)$ than the diapausing larvae was the larvae stored for 2 years (Fig. 2A).

Water loss and water uptake of larvae exposed to normal storage temperature

Larvae stored for 2 years, when exposed to dry air at storage temperatures, lost water at a significantly $(F=24.073$,
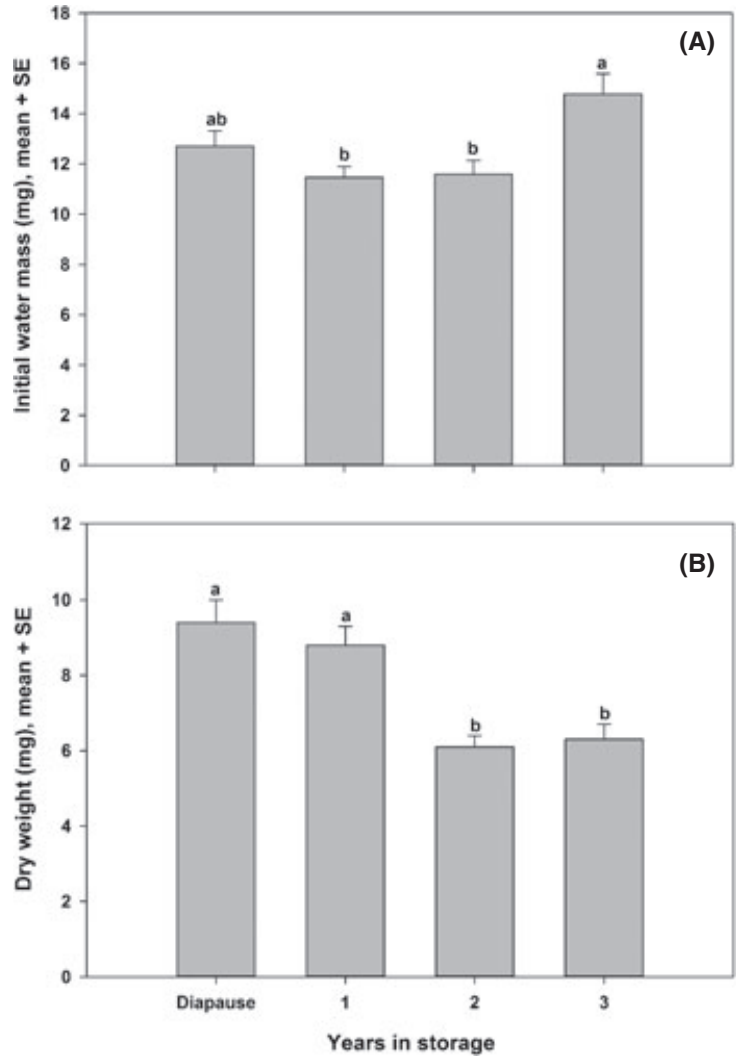

Fig. 1. (A) Initial water mass and (B) dry weights of diapausing and stored Tetanops myopaeformis larvae (mean \pm SEM). Larvae were maintained at $4-6{ }^{\circ} \mathrm{C}$ for less than 3 months (diapausing), and 1,2 or 3 years. Each bar is based on 20 larvae. Bars sharing the same lowercase letter are not significantly different $(P<0.05$, Tukey's multiple comparison procedure).

d.f. $=1, P<0.001)$ higher rate $\left(0.68 \% \mathrm{~h}^{-1}\right)$ than diapausing larvae $\left(0.48 \% \mathrm{~h}^{-1}\right)$ (Fig. 2B). Once larvae lost water, exposing them to either $100 \%$ relative humidity or placing them onto moistened filter paper failed to rehydrate them, which indicates that T. myopaeformis larvae are unable to take up water actively at low temperatures (data not shown).

\section{Water loss after a freezing event}

The mean larval wet weights before $(23.1 \pm 1.1 \mathrm{mg})$ and after freezing $(23.0 \pm 1.1 \mathrm{mg})$ were not significantly different between wet- or dry-frozen larvae $(P>0.05)$ (Fig. 3). The water loss rates for larvae under these conditions were $1.9 \% \mathrm{~h}^{-1}$ (frozen dry), $2.8 \% \mathrm{~h}^{-1}$ (frozen wet) and $2.1 \%$ $\mathrm{h}^{-1}$ (nonfrozen controls), and were not significantly different (Kruskal-Wallis rank test: $H=5.118$; d.f. $=2 ; P=0.077$ ).

\section{Discussion}

Surviving prolonged cold storage requires the sugarbeet maggot $T$. myopaeformis to maintain homeostasis under very 


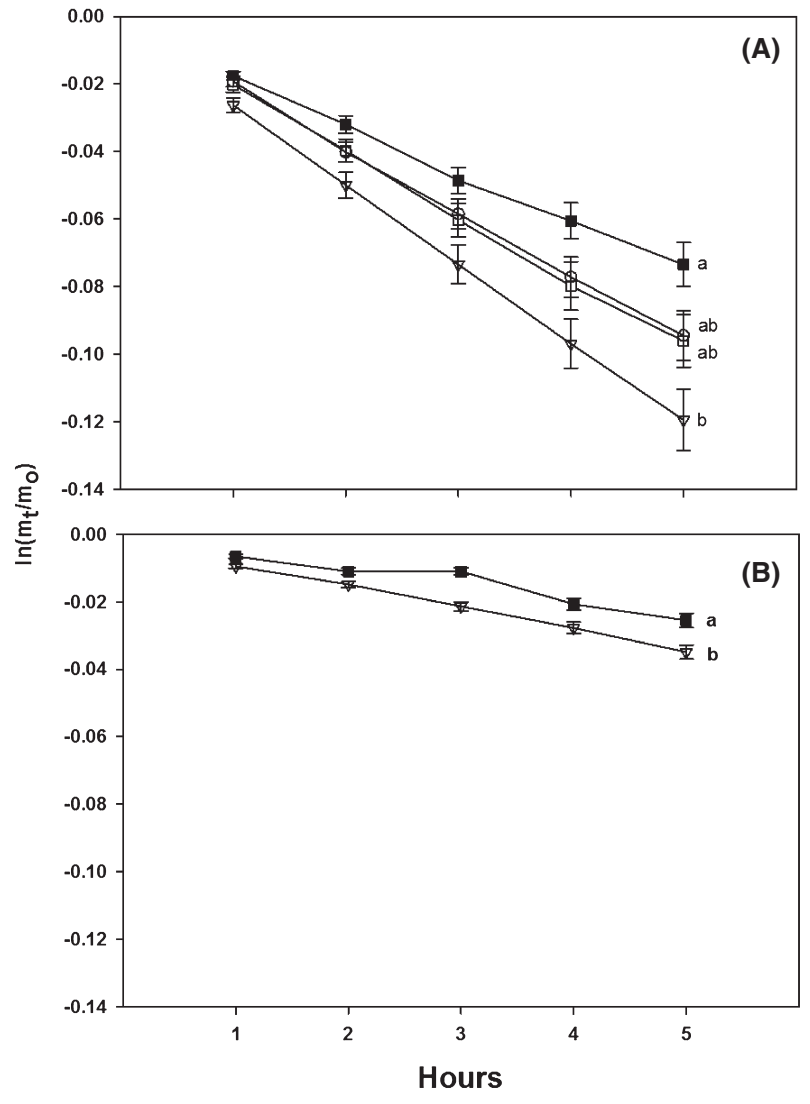

Fig. 2. Water loss of diapausing and stored Tetanops myopaeformis larvae exposed to (A) dry air at room temperature or (B) normal storage temperature (mean $\pm \mathrm{SEM}$ ). Larvae were maintained at $4-6{ }^{\circ} \mathrm{C}$ for less than 3 months diapausing (solid squares), and 1 year (open squares), 2 years (triangles) or years 3 (circles). Means are based on 12 larvae in (A) and 20-29 larvae in (B). Curves with the same lowercase letter are not significantly different $(P<0.05$, Tukey's multiple comparison procedure).

unnatural conditions. As measured by initial water mass with up to 3 years in storage, larvae of T. myopaeformis show a remarkable ability to maintain this critical resource within a narrow range. The percentage body water values for larvae $(57.0-70.1 \%)$ are within the normal range recorded in other insects (Wharton, 1985; Danks, 2000). This is also consistent with the findings of Chirumamilla et al. (2010). Specifically, wet weights of $T$. myopaeformis larvae remain stable over a course of 5 years in storage; however, after 2 years, there is a significant decrease in the dry weight of the stored larvae compared with diapausing controls. Similar results are found in the present study, except that the dry weights of the larvae stored for 2 years are significantly different from the diapausing larvae and larvae stored for 1 year. Insects use a number of different means to acquire water (e.g. feeding, drinking, active and passive absorption of atmospheric water and water generated by metabolism) (Chown \& Nicolson, 2004). Larvae at the normal storage temperature of $4-6{ }^{\circ} \mathrm{C}$ are immobile and therefore cannot gain water from food or drinking. The present study demonstrates that these larvae

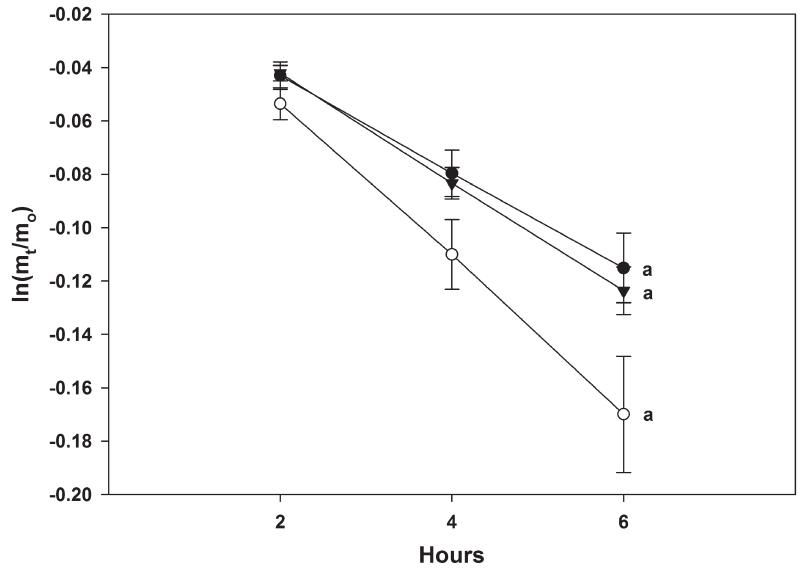

Fig. 3. Water loss in Tetanops myopaeformis larvae after a freezing event (mean \pm SEM). Larvae were maintained at $4-6{ }^{\circ} \mathrm{C}$ for 1 year. Larvae were frozen either dry (solid circles) or in direct contact with water (open circles). Control larvae (solid triangles) were not frozen before the water loss experiment. Means are based on 12- 25 larvae. Curves sharing the same lowercase letter are not significantly different $(P<0.05$, Tukey's multiple comparison procedure).

are unable to uptake water actively or passively from the atmosphere during storage. Metabolic water appears to be the primary means by which larvae of $T$. myopaeformis maintain water balance during storage.

It is one thing for the larvae to be able to maintain their water balance under the high humidity conditions of the normal storage method. However, increasing the stress on the larvae by exposing them to $0 \%$ relative humidity could provide insights into how larval vigour changes during storage as they respond to this potentially lethal stress. At room temperature, larval water loss rates vary in the range $1.4-2.2 \% \mathrm{~h}^{-1}$. The only group of larvae that lose water at a significantly higher rate than the diapausing controls are the larvae stored for 2 years. Water loss in the larvae stored for 3 years is not significantly different from that of the diapausing larvae. Lowering the temperature to the normal storage temperature decreases the water loss rate, although the larvae stored for 2 years lose water at a significantly high rate $\left(0.68 \% \mathrm{~h}^{-1}\right)$ compared with diapausing controls $\left(0.48 \% \mathrm{~h}^{-1}\right)$. The larvae used in these two experiments have different collection years, suggesting that the increased water loss rate seen in the 2-year stored larvae is a result of some other environmental factor that the larvae are exposed to before entering storage.

An examination of water loss rates after a freezing event identifies no significant differences between control larvae and those exposed to freezing. According to Rinehart et al. (2009), stored T. myopaeformis are able not only to maintain water balance after they have been frozen, but also to adjust other key physiological components to survive future stresses. The supercooling points of larvae stored for 1 year vary by $11.8^{\circ} \mathrm{C}$ from -7.2 to $-19.0^{\circ} \mathrm{C}$. After a freezing event and subsequent recovery at $25{ }^{\circ} \mathrm{C}$, the range of supercooling points of larvae stored for 1 year decreases to only $4{ }^{\circ} \mathrm{C}\left(-6.0\right.$ to $\left.-10.0{ }^{\circ} \mathrm{C}\right)$, with both magnitude and absolute values at a range seen in diapausing nonstored larvae (Rinehart et al., 2009). These results 
indicate that, even after 1 year in storage, T. myopaeformis larvae are still sufficiently healthy to respond appropriately to serious environmental stressors such as freezing.

In conclusion, storage even for 3 years does not affect the ability of T. myopaeformis larvae to maintain water balance. These results reinforce the findings of earlier studies indicating that storage for 3 years has very little discernible direct fitness cost to T. myopaeformis larvae (Chirumamilla et al., 2008). Three key factors are considered to be involved in the ability of T. myopaeformis larvae to survive multi-year laboratory storage: (i) the larvae are either in a state of prolonged diapause or post-diapause quiescence, which are naturally occurring physiological stages optimized for surviving prolonged or recurrent low-temperature stress (Chirumamilla et al., 2008); (ii) the overwintering larvae possess uncommonly large metabolic reserves (Chirumamilla et al., 2010); and (iii) exposing larvae to $4-6{ }^{\circ} \mathrm{C}$ in non-moistened sand results in $100 \%$ mortality within approximately 7 days (M. A. Boetel, unpublished observations). The rates of water loss observed in this investigation explain these observations and reinforce the importance of the high-moisture microenvironment needed by this organism. Understanding the relative contributions and interactions between each of these factors (as well as other possible undiscovered factors) affecting the larval tolerance of T. myopaeformis to prolonged storage could provide valuable insights into how to optimize storage protocols for other insect species.

\section{Acknowledgements}

We thank the two anonymous reviewers for their constructive comments that improved this manuscript, as well as Marnie Larson for her technical and editorial assistance.

\section{References}

Anderson, A.W. (1986) Biology and control of sugarbeet root maggot. Sugarbeet Research and Extension Reports, 17, 89-97.

Bechinski, E.J., McNeal, C.D. \& Gallian, J.J. (1989) Development of action thresholds for the sugarbeet root maggot (Diptera: Otitidae). Journal of Economic Entomology, 82, 608-615.

Bechinski, E.J., Everson, D.O., McNeal, C.D. \& Gallian, J.J. (1990) Forecasting peak seasonal capture of sugarbeet root maggot (Diptera: Otitidae) with sticky-stake traps in Idaho. Journal of Economic Entomology, 83, 2078-2085.

Callenbach, J.A., Gojmerac, W.L. \& Ogden, D.B. (1957) The sugarbeet root maggot in North Dakota. Journal of the American Society of Sugar Beet Technologists, 9, 300-304.

Chirumamilla, A., Yocum, G.D., Boetel, M.A. \& Dregseth, R.J. (2008) Multi-year survival of sugarbeet root maggot (Tetanops myopaeformis) larvae in cold storage. Journal of Insect Physiology, 54, 691-699.

Chirumamilla, A., Buckner, J.S., Yocum, G.D. et al. (2010) Internal lipids of sugarbeet root maggot (Tetanops myopaeformis) larvae: effects of multi-year cold storage. Comparative Biochemistry and Physiology B, Biochemistry and Molecular Biology, 157, 73-70.

Chown, S.L. \& Nicolson, S.W. (2004) Insect Physiological Ecology: Mechanisms and Patterns. Oxford University Press, U.K.

Danks, H.V. (2000) Dehydration in dormant insects. Journal of Insect Physiology, 46, 837-852.

Foerster, L.A. \& Doetzer, A.K. (2006) Cold storage of the egg parasitoid Trissolcus basalis (Wollaston) and Telenomus podisi Ashmead (Hymenoptera: Scelionidae). Biological Control, 36, 232-237.

Harper, A.M. (1962) Life history of the sugarbeet root maggot Tetanops myopaeformis (Röder) (Diptera: Otitidae) in southern Alberta. Canadian Entomologist, 94, 1334-1340.

Garcia, P.V., Wajnberg, E., Pizzol, E. \& Oliveira, M.L.M. (2002) Diapause in the egg parasitoid, Trichogramma cordubensis: role of temperature. Journal of Insect Physiology, 48, 349-355.

Gilkeson, L.A. (1990) Cold storage of the predatory midge Aphidoletes aphidimyza (Diptera: Cecidomyiidae). Journal of Economic Entomology, 83, 965-970.

Leopold, R.A. (1991) Cryopreservation of insect germless: cells, tissues, and organisms. Insects at Low Temperature (ed. by R. E. Lee Jr and D. L. Denlinger), pp. 379-407. Chapman and Hall, U.K.

Leopold, R.A. (1998) Cold storage of insects for integrated pest management. Temperature Sensitivity in Insects and Application in Integrated Pest Management (ed. by G. J. Hallman and D. L. Denlinger), pp. 235-267. Westview, Boulder, Colorado.

Leopold, R.A. (2007) Colony maintenance and mass-rearing using cold storage technology for extending the shelf-life of insects. AreaWide Control of Insect Pest: From Research to Field Implementation (ed. by M. J. B. Vreysen, A. S. Robinson and J. Hendrichs), pp. 149-162. Springer, The Netherlands.

Rinehart, J.P., Yocum, G.D., Chirumamilla-Chapara, A. \& Boetel, M.A. (2009) Supercooling point plasticity during cold storage in the freeze-tolerant sugarbeet root maggot Tetanops myopaeformis. Physiological Entomology, 34, 224-230.

Tauber, M.J., Taube, C.A. \& Gardescu, S. (1993) Prolonged storage of Chrysoperla carnea (Neuroptera: Chrysopidae). Environmental Entomology, 22, 843-848.

Van Lenteren, J. \& Woets, J. (1988) Biological control in greenhouses. Annual Review of Entomology, 33, 239-269.

Wharton, G.W. (1985) Water balance of insects. Comprehensive Insect Physiology Biochemistry and Pharmacology (ed. by G. A. Kerkut and L. I. Gilbert), Vol. 4, pp. 565-601. Elsevier Press, The Netherlands.

Whitfield, G.H. \& Grace, B. (1985) Cold hardiness and overwintering survival of the sugarbeet root maggot (Diptera: Otitidae) in Southern Alberta. Annals of the Entomological Society of America, $\mathbf{7 8}$, 501-505.

Yoder, J.A. \& Denlinger, D.L. (1991) Water balance in flesh fly pupae and water vapour absorption associated with diapause. Journal of Experimental Biology, 157, 273-286.

Yoder, J.A. \& Denlinger, D.L. (1992) Water vapour uptake by diapausing eggs of a tropical walking stick. Physiological Entomology, 17, 97-103.

Yoder, J.A., Rivers, D.B. \& Denlinger, D.L. (1994) Water relationships in the ectoparasitiod Nasonia vitripennis during larval diapause. Physiological Entomology, 19, 373-378.

Accepted 14 July 2012

First published online 17 August 2012 